\title{
Moral Reflections and Sacred Constraints: About a lucus at Gabii
}

\section{Chantal Gabrielli}

In this paper, I am going to develop the question whether ethics or ritualism conditioned human behaviour in Roman polytheism by analysing the conceptual mechanism of orthopraxy, focusing upon standardized ritual rather than standardized belief, through an obscure episode of the Third Samnite War. ${ }^{1}$ This episode involves a member of the gens Postumia in the ager Gabinus, whose sacredness and special position of territory in augural doctrine is well attested in the literary sources. I am going to concentrate on L. Postumius Megellus. He had been consul three times (305, 294, 291), and played an important role in the Third Samnite War, but in the literary sources there were accounts of a trial, a conviction and also conflicts involving imperium between him and the senate.

Modern historians offer different theories about his indictment and the date of the trial. There was a historiographical tradition hostile to the gens Postumia, whose arrogance and pride and the tendency of its members to anger were well known. ${ }^{2}$ Some scholars prefer to follow the hostile account of Dionysius of Halicarnassus, who connects the indictment with a series of despotic acts carried out by Postumius during his consulship. ${ }^{3}$ As another possible bias, it is also necessary to underline how offences against human and divine laws were frequent in annalistic accounts of unpopular commanders. ${ }^{4}$

What do the ancient reports tell us that happened?

According to a passage in the Periocha of Livy Book XI, ${ }^{5}$ Postumius was convicted for using his soldiers' labour for personal interest during his

1 About the political implications of the episode see my article "Lucius Postumius Megellus at Gabii: a new fragment of Livy," Class. Qu. 53.1 (2003), 247-259.

2 G. Firpo, "Silla e i Postumii: un 'processo' storiografico?," in M. Sordi (a cura di), Processi e politica nel mondo antico, CISA 22, (Milano, 1996), 153-166, 160 n. 29 e 166 n. 47; Id., "Tradizioni gentilizie e storiografia: a proposito dei trionfi degli anni 294291 a.C.," in Atti e Memorie della Accademia Petrarca di Lettere, Arti e Scienze, n. s. 62 (2000), 329-346, esp. 336-337, 340-342, 345-346.

3 B. Bruno, "La terza guerra sannitica," in Studi di storia antica pubblicati da Giulio Beloch 6 (Rome, 1906), 87-9, 102.

4 F. Münzer in RE XXII.1 (1953), Postumius 55 (cc. 935-41), c. 939.

5 Perioch., 11: L. Postumius consularis, quoniam, cum exercitui praeesset, opera militum in agro suo usus erat, damnatus est. 
consulship. A long excerptum from the Roman Antiquities of Dionysius of Halicarnassus and a Suda entry also insist on the gravity of his action, while an excerptum by Cassius Dio reports that Postumius was recalled by the senate, because the soldiers became ill after cutting down some trees. ${ }^{6}$ However, Dionysius of Halicarnassus records that Postumius was condemned in the comitia tributa to pay a large fine. ${ }^{7}$

A papyrus fragment, written in the Vth cent. AD and found in 1986 in Egypt, talks about two different episodes from Livy 11 (this was suggested by B. Bravo and M. Griffin, ${ }^{8}$ and confirmed by R. E. A. Palmer and M. A. Vinchesi ${ }^{9}$ ). The fragment, which has text on either side, reports two different episodes connected with Postumius Megellus' military actions during his third consulship in 291 B.C.

Side A of the fragment makes a reference to Gabii. A new army had been ordered to assemble there and had been organized into centuries, and probably a contingent of two thousand soldiers had left from there for a consul's estate, located near the Latin town. ${ }^{10}$ Side B is the final part of a message reported in oratio obliqua and sent to someone called Fabius. As well as locating the estate, the author also specifies that the soldiers were pedites. The importance of the fragment lies especially in Side A, which contains a piece of information (the reference to Gabii) that is not present in the other sources.

The fragment in question, then, deals both with an obscure period in the history of Rome and with a city that played a crucial role in Roman religion. It is precisely this combination that justifies further discussion of this text. So I would like to suggest other explanations of the nature of consul's order to cut down the trees and the consequences of this act, in addition to the traditional interpretation of the abuse of authority: by reading the Postumius' episode as one significant account which provided the basis for later policing actions

6 Dion. Hal., 17/18.4.1-6; 5.1-4; Suidae Lexicon s.v. Побтó 2118; Dio, 8. fr.36.32.

7 Dion. Hal., 17-18.5.4.

8 B. Bravo and M. Griffin, "Un frammento del libro XI di Tito Livio?," Athenaeum 66 (1988), 447-521.

9 R. E. A. Palmer, "A new fragment of Livy throws light on the Roman Postumii and Latin Gabii," Athenaeum 78 (1990), 5-18; M. A. Vinchesi, "Notizia su un probabile frammento di Tito Livio," Atene e Roma 35 (1990), 176-82. The other sources are conveniently collected in M. R. Torelli, Rerum Romanarum Fontes ab an. 292 ad an. 265 a.C. (Pisa, 1978), 43-5.

10 [- ... ing]ens [ei era]nt ha[u]t pro[cul G]abiis [u]rbe. cu(m) [Ga]uios nouos exer[cit]us indictus [e]sset ibique centuriati milites essent, cum duob(us) milib(us) pe[\{.\}]ditum profect $[u] s$ in agru(m) suom cons[ul? 1-2 lett.]. In A, I, 4 one can read with enough probability the name of the Latin town G]abiis (Stefan Meyer in Bravo and Griffin (n.8), 473-4); while in the following line A, I, 5 [Ga] uios instead of Gabios is a banal spelling variant. 
against deviant forms of religion throughout much of the subsequent history of sacred Roman law.

The antiquarian sources present Gabii as a city which was famous for its Greek culture ${ }^{11}$ and religious influence on Rome, as the literary tradition on the cinctus Gabinus shows. Dionysius of Halicarnassus (1.84.5) and Plutarch (Rom. 6.2), for example, tell us that Romulus and Remus were sent to Gabii where they were instructed in Greek learning such as letters, music and the use of Greek weapons. Furthermore we know from Varro that the ager Gabinus had a special status that situated it conceptually between ager Romanus and ager peregrinus: Gabinus (ager) quoque peregrinus, sed quod auspicia habet singularia ab reliquo discretus (De ling. lat., 5.33). Even if it is not possible to define exactly the particular nature of the auspices of Gabii, it is clear that the territory occupied a special position in augural doctrine. ${ }^{12}$ The location of Postumius' estate near the town of Gabii is perhaps not unexpected: there had been close connections from the fifth century B.C. onwards between the gens Postumia, with their interest in Greek cults, ${ }^{13}$ and the territory of Gabii, although we do not know when any member of the gens had acquired land in the ager Gabinus. ${ }^{14}$

From the literary sources we know some details about the consul's estate. We suppose that the property was large. Indeed the use of two thousand men is remarkable, if compared with the small number of labourers needed for an olive grove or a vineyard as suggested by Cato. ${ }^{15}$

The fragment reports that the contingent of soldiers was marching in agrum suom, while the Periocha of Livy gives the same information, in agro suo; but the text of the fragment, in the first and second line, is incomplete. What came before the sentence [-...- ing]ens [ei era]nt ha[u]t pro[cul G]abiis [u]rbe, according to Bravo's restoration, may be an expression such as villa et ager or, as

11 E. Peruzzi, "Romolo e le lettere greche," Parola del Passato 24 (1969), 161-89; revised in id., Origini di Roma, II, (Bologna, 1973), 9-53; id., "Grecità del Lazio preromano," in id., Civiltà greca nel Lazio preromano (Florence, 1998), 165-77.

12 P. Catalano, "Aspetti spaziali del sistema giuridico-religioso romano. Mundus, templum, urbs, ager, Latium, Italia," ANRW 2.16.1 (1978), 440-553, esp. 494-5.

13 See L. Monaco, "La gens Postumia nella prima repubblica. Origini e politiche," in G. Franciosi (ed.), Ricerche sulla organizzazione gentilizia romana, III, (Naples, 1995), 267 98.

14 There are no grounds for the date of 338 B.C. suggested by Palmer (n.9), 5, on the basis of a corrupt passage of Macrobius (Sat., 3.9.13); Palmer also, like the Loeb edition, clearly mistranslates Dion. Hal. 17/18.4.1, which refers to the succession to the consulship, not to hereditary succession. There is not doubt that Postumius had an estate near Gabii: N. Terrenato, A. Gallone, J. A. Becker, S. Kay, "Urbanistica ortogonale a Gabii. Risultati delle nuove prospezioni geofisiche e prospettive per il futuro," in G. Ghini (a cura di), Lazio e Sabina 6. Atti del Convegno Sesto Incontro di Studi sul Lazio e la Sabina, Roma 4-6 marzo 2009, (Rome, 2010), 237-248.

15 Cato, De agric., 10. 
Griffin suggested, ager et saltus. ${ }^{16}$ The latter is more probable, because it is a frequent combination in Livy. ${ }^{17}$ Moreover it fits better with the accounts of Dionysius, Dio and the Suda, because they report tree-felling on the estate, which would imply the existence of a woodland area to which the word saltus could allude. In fact Dionysius and the Suda, which repeats Dionysius almost word for word, mention a $\delta \rho v \mu o ́ s$, that is a wood, a thicket; while Cassius Dio with the word $\alpha \lambda \lambda \sigma o \varsigma$ alludes to the existence of a lucus. ${ }^{18}$ Given that the word lucus, etymologically linked to lux, must originally mean not 'sacred wood', but 'sacred glade', artificially created by human intervention inside a wood (nemus or silva), ${ }^{19}$ the difference between Dionysius' $\delta \rho u \mu$ ó and Dio's ớ $\lambda \sigma o \zeta$ suggests that the consul's estate included a woodland area containing a lucus. ${ }^{20}$ We know that in ancient Italy every oak was sacred to Jupiter, ${ }^{21}$ so a wood with sacred oaks could fit better with the existence of a lucus/ón $\sigma 0 \varsigma$. Moreover the morphological analysis of the soil and archaeological evidence around Gabii reveals that in antiquity the area included healing sanctuaries and the cult of a sacred tree in the temple of Juno Gabina, which was surrounded by a lucus. ${ }^{22}$

It is possible that, already in the third century B.C., sacred areas of the peninsula were violated in order to obtain more land, as Frontinus assumes for a later period. ${ }^{23}$ In this case, Megellus' prohibition on the use of iron to cut down

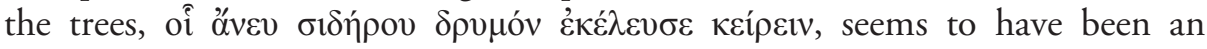

16 Bravo and Griffin (n.8), 474.

17 Vinchesi (n.9), 181.

18 Stephanus, TLG I, $1581-2$ s.v. $\alpha^{\prime} \lambda \sigma o \zeta$.

19 F. Coarelli, "I luci del Lazio: la documentazione archeologica," in Les Bois sacrés (Collection du Centre Jean Bérard 10, Naples, 1993), 47-8. Contra I. Cazzaniga, "Lucus a non lucendo," Stud. Class. Orient. 21 (1972), 27-9, who, in a discussion of the connexion between lucus and lux, presents instead the etymological solution lucus a non lucendo.

20 Firpo, Silla e i Postumii (n.2), 166 n. 47 spoke specifically about an oak wood, the consul should have ordered his soldiers to cut down an oak wood in his estate, but he doesn't give any explanation of how he thought of such a thing about the nature of the thicket. I supposed that he probably thought of the etymology of the greek word $\delta \rho u \mu$ ó (in Dionysius and Suda), linked to $\delta \rho \hat{v} \varsigma$, that is the oak tree. - I had the opportunity of speaking with Prof. Firpo, so I could clarify this point directly with him. He substantially confirmed my assumption.

21 Virg., Georg., 3, 332. A. B. Cook, "Zeus, Jupiter, and the Oak", Class. Rev. 18 (1904), $360-375$, 362, said that the Querquetulani were members of the Latin League inhabiting an oak-clad district identified with Corcollo between Gabii and Hadrian's Villa at Tivoli.

22 S. Musco, C. Morelli, M. Brucchietti, "Ager Gabinus: note di topografia storica," Archeologia Laziale 12.1 (1995), 284, 287 ff.; T. Potter, "A Republican healing sanctuary at Ponte di Nona," Journ. Brit. Arch. Ass. 138 (1985), 23-47; for further bibliography see Gabrielli (n.1), 247, 251-252.

23 De controversiis 56.19 Th. $=87.19$ La.: in Italia autem densitas possessorum multum improbe facit et lucos sacros occupat. 
attempt to avoid sacrilege by applying a religious rule for the maintenance of land sacred to the gods. A sacred wood (lucus) was a locus sacer and it covered an important religious role with severe laws to keep. ${ }^{24}$

When a Roman made a clearing in the forest for the pasturing of cattle or the reclamation of new arable land, as I think that Postumius did, it was necessary to appease the unknown spirits whose domain had been poached upon, that they might work no ill on the cattle to be pastured or on the crops to be planted there. Cato in his de agricultura has left us an account of such a ceremony. ${ }^{25}$ It was not only intended as an atoning sacrifice, but also was thought to add strength to the spirits addressed. From the text we know that lucum conlucare, which meant not simple pruning but the felling of trees in order to create a lucus, had to be preceded by an expiatory sacrifice (piaculum), also if somebody is minded to do any digging in a lucus, he has to offer a second atoning sacrifice in the same way, to appease and to make the gods favourable and propitious, to whom the plants, disturbed by this operation, were sacred. ${ }^{26}$ In the acts of the Fratres Arvales we find the description of a sacrifice to Dea Dia to expiate the periodic intrusion of those who worked on the maintenance of the sacred wood ${ }^{27}$ and the necessary introduction of iron tools. ${ }^{28}$ The Lex Luci

24 S. Panciera, "La lex luci Spoletina e la legislazione sui boschi sacri in età romana," in Monteluco e i Monti Sacri. Atti dell'incontro di studio, Spoleto, 30 settembre - 2 ottobre 1993, CISAM, (Spoleto, 1996), 25-50, spec. 35-38. For a wide analysis in a comparative key of sacred groves see K. Dowden, European Paganism. The Realities of Cult from Antiquity to the Middle Ages, chapter VI, (London, 2000).

25 Cato, De agric., 139-140: Lucum conlucare Romano more sic oportet. Porco piaculo facito, sic verba concipito: "Si deus, si dea es, quoium illud sacrum est, uti tibi ius est porco piaculo facere illiusce sacri coercendi ergo harumque rerum ergo, sive ego sive quis iussu meo fecerit, uti id recte factum siet, eius rei ergo te hoc porco piaculo immolando bonas preces precor, uti sies volens propitius mibi domo familiaeque meae liberisque meis; harumce rerum ergo macte hoc porco piaculo immolando esto'. Si fodere voles, altero piaculo eodem modo facito, hoc amplius dicito : "operis faciundi causa"...

26 On the Italic cult of trees and woods, sometimes identified with the god to whom they were dedicated, see G. Stara-Tedde, "I boschi sacri dell'antica Roma," Bullettino della Commissione Archeologica Comunale in Roma 33 (1905), 189-232; id., "Ricerche sulla evoluzione del culto degli alberi dal principio del sec. IV in poi," ibid. 35 (1907), 12981. On the definition of a sacred wood see J. Scheid, “Lucus, nemus: Qu'est-ce qu' un bois sacré?, " in Les Bois sacrés (n.19), 13-20; C. Otto, "Lat. lūcus, nemus 'bois sacré' et les deux formes de sacralité chez les Latins," Latomus 59 (2000), 3-7.

27 On the topography of the lucus deae Diae see J. Scheid, Romulus et ses Frères. Le Collège des Frères Arvales, modèle du culte public dans la Rome des Empereurs (BEFAR 275, Rome, 1990), 95-182; for the terminology used to define the maintenance of a sacred wood, that is lucum coinquere, opus facere, see H. Broise and J. Scheid, "Étude d'un cas: le lucus deae Diae à Rome," in Les Bois sacrés (n.19), 145-57.

28 J. Scheid, Commentarii Fratrum Arvalium qui supersunt (Rome, 1998), n. 94 col. III 11. 19-20 etc. Ovid., Met., 8.741-2: Ille etiam Cereale nemus violasse securi / Dicitur et lucos ferro temerasse vetustos. 
Spoletina prescribed a piaculum for the same reason too. This lex, dated around the second half of the third century $\mathrm{BC}$ and the beginning of the second century $\mathrm{BC}$, is one of the most important epigraphic evidence about the existence of luci in the Roman world. Otherwise this Lex luci Spoletina distinguished those who simply violated the laws connected with the maintenance of the sacred wood (pruning and felling of trees, removal of wood) from those who did it on their own will (scies dolo malo). In this latter case the lex Luci prescribed an expiatory sacrifice and a fine to pay. Using iron was normally forbidden, because this metal was considered taboo in early Roman religion. ${ }^{29}$ This superstitious objection to iron perhaps dates from the beginning of the Iron Age when religious conservatism forbade the use of this strange new material in place of the usual bronze. Over time, the refusal of iron became less absolute: as I said before, the Arval Brothers came to offer an atoning sacrifice before taking the iron instrument into the grove and again after removing it. The refusal to use of iron presumably meant the use of another material, such as bronze. Among the farm tools used for a vineyard, Cato (De agric., 11.4) reports rush-hooks (falces sirpiculae), tree-hooks (falces silvaticae) and pruning-hooks (falces arborariae), probably the equipment used by Postumius' milites. The consul had perhaps acquired land including a sacred wood, but one which was not under the control of a town or of a sanctuary, with an abandoned lucus so overgrown that the trees, which should have bordered it, had now encroached on the open space. One possibility is that Postumius, respecting tradition, wished to restore a sacred area on his estate. On the other hand it is possible that he wanted to use the labour of his soldiers to clear the wood and use the land for agriculture. Smit, in the Loeb edition of Dionysius of Halicarnassus, wants to evade the problem created by

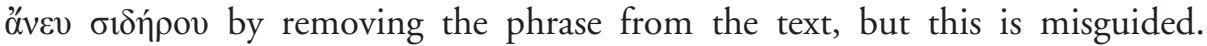
Forbidding the use of iron reveals a religious rule connected with the existence of a lucus in the consul's estate. This aspect makes it probable to explain Postumius' indictment from that obscure episode. Dionysius of Halicarnassus records that Megellus was condemned in the comitia tributa to pay a large fine. If we look at the religious rules in the Lex Luci Spoletina we could suppose that Postumius has to pay a fine because he has intentionally broken a religious law with his behaviour. From this point of view the indictment and the trial recorded in the literary sources would have the function to demonstrate how the Senate acted, which was its logic, in the control of deviant religious behaviour. In a recent article Scheid ${ }^{30}$ underlined the gravity of the intentional irreligious-

29 On the religious consequences of this prohibition see A. Pasqualini, s.v. lucus, in E. De Ruggiero, Dizionario epigrafico, IV, 62/63, (Rome, 1975), 1969-1989.

30 J. Scheid, "Appartenenza religiosa ed esclusione dalla città," in A. Corbino - M. Humbert - G. Negri (a cura di), Homo, caput, persona. La costruzione giuridica 
ness, dolo malo. A civis who has intentionally offended the gods, profaning and destroying their property, as well as a temple and why not a lucus, was moved away from Rome. The impious man was moved away from the civitas, condemned to exclusion from the civil society, because he had broken the religious rules of the gods of the city. In our case, as Dionysius' passage suggested, we could think probable that Postumius' action had been too offensive for a Roman commander in a religious meaning too: his soldiers did not use the forbidden iron tools, however they cut down a sacred grove. Postumius' avoidance of the use of iron implements to cut down the grove provides an example of a habit of trying to keep just within existing religious conventions and rules. His command was restricted to prohibit the use of iron without forbidding that the sacred grove was cut down. Indeed according to Cassius Dio the soldiers became ill. "It was thought their trouble was due to the felling of the grove", affirmed the historian, who clearly believed that the action provoked divine anger, despite the avoidance of iron tools. Valerius Maximus (1.1.19) offers a significant example of a similar sacrilege in the late Republican period and helps us to understand better the Postumius' episode. Turullius, Antony's prefect, had in large part cut down a grove consecrated (lucus) to Aesculapius to make ships for his commander. But Antony's forces had been defeated even as the wicked work (nefarium ministerium) was in progress. The angry god drew Turullius into the grove that he had violated and in that place was killed by Caesarian soldiers. So the prefect paid with his death penalty to the trees already cut down and gave immunity (immunitas) from similar outrage to the survivors. Cassius Dio and Lactantius confirm in substance this tradition. ${ }^{31}$ In both cases the same irreligious action, i.e. the felling of a sacred grove, provoked divine anger. The effects were terrible: the illness of Postumius' soldiers and the defeat suffered by Antony's forces. We talk about a decrease in the number of soldiers in periods of heavy military commitment. A penalty to pay to have cut down a sacred grove appears necessary not only in a strictly ritual perspective but also considering the relations between warfare and religion.

From what Cassius Dio reported, combined with what we know of the area of Gabii, we can make a further inference about Postumius' estate. It is very probable that the extended stay of the legionaries in marshy and maybe unhealthy places caused an epidemic. Although Gabii itself lays on high ground, the surrounding area includes the marsh of the Pantano Borghese. Archaeological surveys in the ager Gabinus have revealed tunnels for water drainage, and

dell'identità nell'esperienza romana. Dall'epoca di Plauto a Ulpiano, Collegio di Diritto Romano 2008 Cedant, (Pavia, 2010), 347-365.

31 Dio 51.8.2-3; Lactant., Inst., 2.7.17. Turullius, one of Caesar's assassins, fell into the hands of Octavian the year after Actium, who had him executed at the scene of his sacrilege. 
a complex system of drainage, dating back to the mid-Republican period, has also been found in two excavations in the ager Gabinus. ${ }^{32}$ Unfortunately, our sources do not tell us how many soldiers out of the two thousand died. In a period of heavy military commitment, during the Third Samnite War, any decrease in the number of soldiers would have been serious. A report of loss or temporary indisposition would have obliged the senate to seek the causes. The episode of 291 B.C. is mentioned by Cassola as an example of disagreement between consul and senate, along with others in which Postumius claimed the supremacy of the consular imperium. ${ }^{33}$ To the accusation of abuse of authority vis-à-vis the soldiers, the consul answered that the senate did not rule over him, but he ruled over it, ${ }^{34}$ using words similar to those Dionysius attributes to him on another occasions. ${ }^{35}$ All this shows that his rebellious behaviour against the senate left a deep mark on the tradition.

In conclusion, the discovery of this fragment with reference to Gabii has substantially enriched the literary tradition on obscure episode of the Third Samnite War. That the consul's estate also included marshy areas and a sacred grove (lucus), besides fields, is a very probable hypothesis, also considering the morphology of the soil around Gabii. The location of the consul's estate also suggests other explanations of his behaviour, besides the traditional one of the abuse of authority. This allows us to interpret his use of soldiers for personal interest as not only the application of traditional aristocratic modes of labour exploitation, which were deep-rooted in the mentality of conservative patricians and had not yet been abandoned by men such as Postumius. Other possible explanations on Postumius' indictment and trial may be sought. If we look at the different logics of forbidding the use of metals we can formulate another probable hypothesis. Ethics and ritualism can have conditioned human behaviour in Roman polytheism. This episode could probably reveal how the Senate wanted to defend a mechanism of orthopraxy, underlining sacred constraints in the laws of a sacred grove and exerting a powerful influence on the control of deviant religious behaviour. So the episode could show an

32 Musco, Morelli and Brucchietti (n.22), 284, $287 \mathrm{ff.}$.

33 F. Cassola, I gruppi politici romani nel III sec. A. C. (Trieste, 1962), 194-8. On the disagreement between Postumius and the senate see L. Loreto, L'epoca di buon senso. Decisione, consenso e stato a Roma tra il 326 e il 264 a. C. (Amsterdam, 1993), 121-2, 184 and id., "Sui meccanismi della lotta politica a Roma tra il 314 e il 294 a.C. Considerazioni su quattro casi," Annali della Facoltà di Lettere e Filosofia, Università di Macerata 24 (1991), 61-76, esp. 74; E. Gabba, "La società romana fra III e IV secolo", in Storia di Roma. II.1. L'impero mediterraneo (Turin, 1990), 9-11.

34 Dio, 8. fr.36.32.

35 Dion. Hal., 17/18.4.5. 
instrumental use by the senate of archaic religious conventions to attack Postumius and his imperium. 
Bereitgestellt von | De Gruyter / TCS Angemeldet | 212.87.45.97

Heruntergeladen am | 05.09.12 11:29 